\title{
THE FRESHWATER SHRIMPS OF CURAÇAO, WEST INDIES (DECAPODA, CARIDEA)
}

\author{
BY \\ ADOLPHE O. DEBROT \\ Carmabi Foundation, Piscaderabaai z/n, P.O. Box 2090, Curaçao, Netherlands Antilles
}

\begin{abstract}
On the basis of a field survey and review of existing records I here report on the occurrence of ten freshwater shrimp species in Curaçao. Four species constitute new and/or previously unpublished records for the island. Existing records for the neighbouring islands of Bonaire and Aruba are reviewed.

The most common species are Macrobrachium carcinus, M. crenulatum, and Xiphocaris elongata. Macrobrachium heterochirus, Micratya poeyi, and Atya scabra appear to be quite rare, while M. lucifugum and Typhlatya monae are limited to karst waters. Survey results for Curaçao reflect the detrimental effects of excessive damming, which blocks surface water flows and thereby prevents lifecycle migration of amphidromous species.
\end{abstract}

\section{RÉSUMÉ}

A partir d'une étude sur le terrain et des données existantes, dix espèces de crevettes d'eaux douces ont été identifiées de Curaçao et font l'objet de ce travail. La présence de quatre de ces espèces constitue des résultats nouveaux ou non encore publiés pour cette île. Les données existantes pour les îles voisines de Bonaire et Aruba sont examinées.

Les espèces les plus communes sont Macrobrachium carcinus, M. crenulatum et Xiphocaris elongata. Macrobrachium heterochirus, Micratya poeyi et Atya scabra apparaissent comme rares, tandis que M. lucifugum et Typhlatya monae sont limitées aux eaux karstiques. Les résultats des prospections sur le terrain à Curaçao reflètent les effets préjudiciables des barrages en excès, qui bloquent l'écoulement de l'eau de surface et empêchent ainsi la migration nécessaire des espèces amphidromes.

\section{INTRODUCTION}

While much information is already available on the rich endemic fauna of hypogean fresh- and brackish water microcrustaceans of Curaçao in general (e.g., Kensley, 1981; Stock, 1976a, 1977b, c, 1979, 1980; Stork, 1940; Wägele, 1982), little is known about the freshwater shrimps. 
Since the review of the decapods published by Chace \& Holthuis (1948), which documented three species of shrimp, three new species records have been published (Holthuis, 1977; Hobbs \& Hart, 1982). As yet, nothing has been done that could be characterized as a truly extensive survey.

To obtain greater insight into the occurrence and present status of shrimp species in freshwater habitats of Curaçao, I conducted a 17-site island survey. Fishes and freshwater sponges were also collected but are reported on separately (Debrot \& Van Soest, 2001; Debrot, in press). This report concerns the shrimps collected, and also provides a review of earlier records, several of which have remained unpublished until now. Descriptions of the species mentioned are not provided here, but can be found elsewhere (Chace \& Hobbs, 1969; also partly in Hobbs \& Hart, 1982; Hobbs et al., 1977).

\section{STUDY AREA AND METHODS}

Curaçao lies in the southern Caribbean, approximately $70 \mathrm{~km}$ from the coast of Venezuela. Total surface area is approximately $444 \mathrm{~km}^{2}$ and the highest point is $375 \mathrm{~m}$ above sea level. Annual mean temperature is $27.5^{\circ} \mathrm{C}$ and annual rainfall averages $566 \mathrm{~mm}$. The vegetation is principally xerophytic. Approximately $50 \%$ of the annual rainfall occurs in October-December. Record levels of rainfall occurred during the 1999 rainy season, particularly in December, when rainfall was about $248 \%$ higher than normal. Continued high levels of rainfall in the first quarter of the new year meant that many streams and dams retained water well into June of 2000.

The island is traversed by a large number of seasonal streams. In addition, a large number of agricultural water catchment dams, most of which were constructed by man during the colonial era, continue to be maintained. I selected ten dams, six streams ("rooi"), and one livestock watering hole ("pos") as principal sampling sites for a reasonable distribution across the island (sites 1-17, fig. 1). All principal sites were extensively sampled for crustaceans and fishes during a single daytime visit using a combination of fine mesh $(4 \mathrm{~mm})$ cast nets and dipnets (JuneJuly 2000). Voucher specimens of all shrimp are deposited in the collections of the National Museum of Natural History, Leiden (RMNH).

I further report observations and/or specimens collected from six supplementary sites that were only studied incidentally (sites a-f, fig. 1), and three sites which were not visited during this study (sites g-i). At all principal sites and several supplementary sites, salinity and conductivity were measured to the nearest $2 \%$ and $0.5 \%$, respectively, using a YSI Inc. Model 30 salinity and conductivity meter, while $\mathrm{pH}$ was measured to the nearest 0.02 unit using a Fisher Accumet Model $230 \mathrm{pH}$ meter. For each site, altitude above sea level (a.s.l.) is reported to the nearest $5 \mathrm{~m}$. 


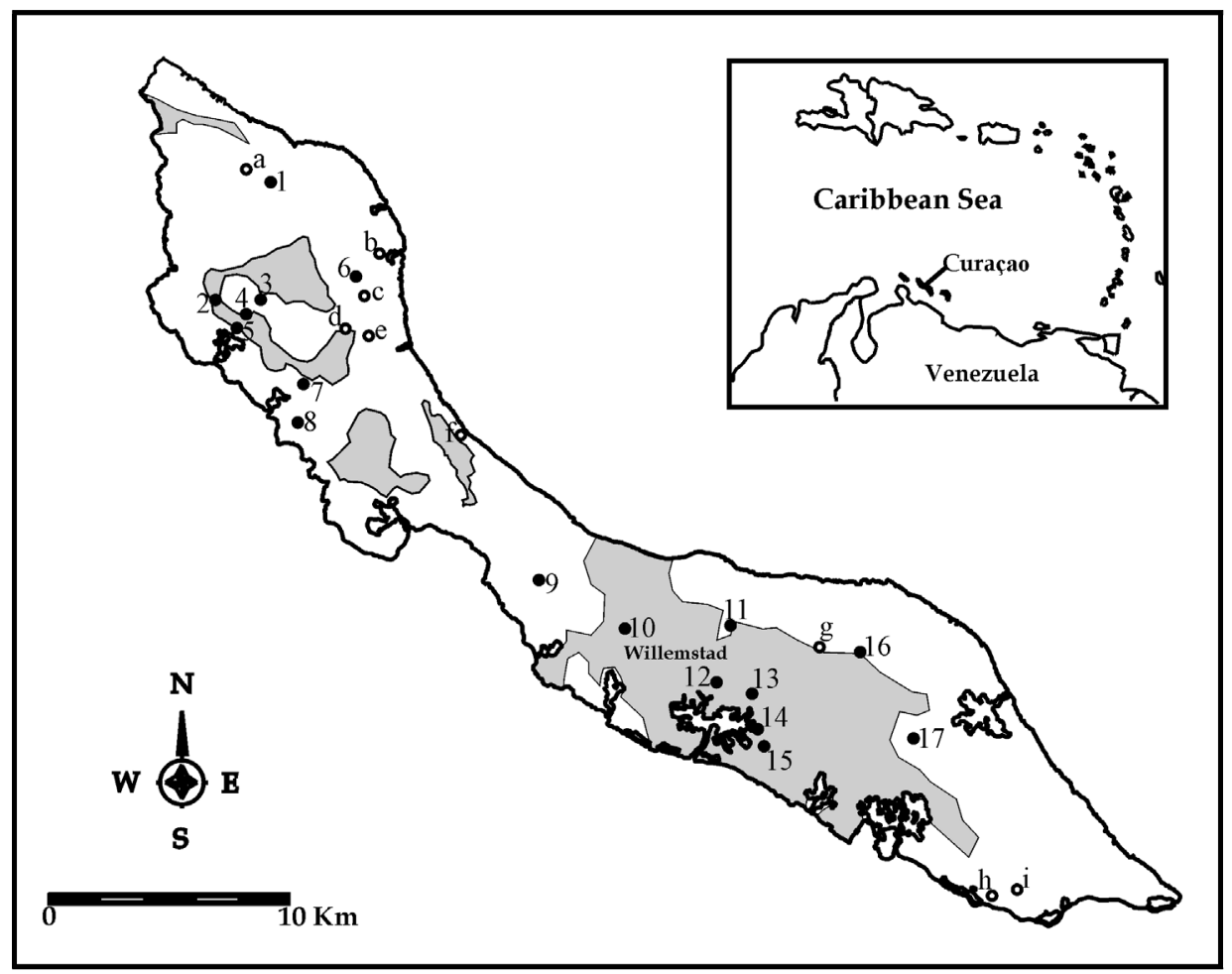

Fig. 1. Map of Curaçao showing principal (1-17) and supplementary (a-f) collection sites, as well as other sites (g-i) referred to in the text but not visited. Shading indicates populated areas.

Table I provides a brief overview of some habitat characteristics of the study sites for which measurements were available. Ranges for water parameter measurements for the 17 principal epigean study sites were as follows; $\mathrm{pH}: 7.15-9.15$, conductivity: 1201-8780 $\mu \mathrm{S}$; salinity: 0.6-4.8 ppt.

All freshwater shrimp species known for Curaçao are listed below, along with the study sites at which each was documented. Brief notes are provided on each species.

\section{SPECIES ACCOUNTS}

\section{ATYIDAE}

Atya innocuous (Herbst, 1792)

Sites. - 1, 2, a.

Remarks. - Prior published records for Curaçao are for Santa Cruz, 1970 (det. L. B. Holthuis) by Kristensen, (1971, 1993), and for Santa Cruz and Hato by Hobbs 


\section{TABLE I}

Habitat characteristics, as available, for principal and supplementary freshwater fauna sampling sites in Curaçao, on dates indicated

\begin{tabular}{|c|c|c|c|c|c|c|c|c|}
\hline Site \# & Location & $\begin{array}{l}\text { Altitude } \\
\text { a.s.l. (m) }\end{array}$ & $\begin{array}{l}\text { Habit } \\
\text { type }\end{array}$ & $\begin{array}{l}\text { ax. depth } \\
\text { (cm) }\end{array}$ & $\mathrm{pH}$ & $\begin{array}{l}\text { Conduct- } \\
\text { ivity }(\mu \mathrm{S})\end{array}$ & $\begin{array}{c}\text { Salinity } \\
\text { (ppt) }\end{array}$ & $\begin{array}{c}\text { Date } \\
(2000 / 01)\end{array}$ \\
\hline \multicolumn{9}{|c|}{ Principal sites } \\
\hline 1 & Rooi Baki, Savonet & 20 & stream & 20 & 8.00 & 1449 & 0.7 & $5 / \mathrm{vi} / 00$ \\
\hline 2 & Rooi, Santa Cruz & 20 & stream & 30 & 8.18 & 1201 & 0.5 & $5 / \mathrm{vi} / 00$ \\
\hline 3 & Dam, Hofi Hooi & 10 & dam & $>100$ & 8.30 & 1772 & 0.9 & 6/vi/00 \\
\hline 4 & Rooi, Hanchi Buriku & 5 & stream & 40 & 8.30 & 1725 & 0.9 & 6/vi/00 \\
\hline 5 & Rooi, Hofi Klein St. Martha & 5 & stream & 40 & 7.15 & 2030 & 1.0 & $5 / \mathrm{vi} / 00$ \\
\hline 6 & Dam, Huish. Sch., Barber & 20 & dam & 80 & 8.80 & 1843 & 1.0 & $5 / \mathrm{vi} / 00$ \\
\hline 7 & Dam di Rio Magdalena & 30 & dam & $>200$ & 9.00 & 1260 & 0.6 & 6/vi/00 \\
\hline 8 & Pos di pia di Dr. Maal & 10 & $\begin{array}{l}\text { water } \\
\text { hole }\end{array}$ & $>500$ & 7.90 & 2411 & 1.2 & $5 / \mathrm{vi} / 00$ \\
\hline 9 & Dam, Malpais & 5 & dam & $>200$ & 8.05 & 2074 & 0.9 & $5 /$ vi/00 \\
\hline 10 & Dam, Soltuna & 15 & dam & 50 & 8.25 & 4092 & 2.2 & 4/vi/00 \\
\hline 11 & Dam di Muizenberg & 20 & dam & $>100$ & 8.35 & 4499 & 2.4 & 6/vi/00 \\
\hline 12 & Rooi, Rio Canario & 10 & stream & 50 & 8.45 & 2781 & 1.6 & 6/vi/00 \\
\hline 13 & Dam, Kabouterbos & 10 & dam & 50 & 8.75 & 4466 & 2.4 & 2/vi/00 \\
\hline $14^{*}$ & Rooi, Bloempot & 5 & stream & 50 & $\begin{array}{l}8.05- \\
8.25\end{array}$ & $\begin{array}{c}1916- \\
5100\end{array}$ & $1-2.7$ & 2/vi/00 \\
\hline 15 & Dam (pos Shera) Girouette & 10 & dam & $>150$ & 7.90 & 2166 & 1.1 & 2/vi/00 \\
\hline 16 & Dam, Hofi Ronde Klip & 30 & dam & $>100$ & 9.15 & 8780 & 4.8 & 6/vi/00 \\
\hline 17 & Dam Pretu, Gr. St. Joris & 15 & dam & $>100$ & 8.10 & 4037 & 2.1 & $5 / \mathrm{vi} / 00$ \\
\hline \multicolumn{9}{|c|}{ Supplementary sites } \\
\hline $\mathrm{a}$ & Pos Shimaron, Savonet & 50 & spring & 50 & 7.71 & 5630 & 3.3 & 6/vii/00 \\
\hline $\mathrm{b}$ & Playa Grandi, Wacao & 0 & salina & $>100$ & 8.15 & 62900 & 40.7 & 13/vii/00 \\
\hline $\mathrm{c}$ & Rooi, Misa Barber & 20 & stream & - & - & - & - & - \\
\hline d & Dokterstuin & 40 & dam & - & - & - & - & \\
\hline $\mathrm{e}$ & Pos Ariba, Dokterstuin & 30 & $\begin{array}{l}\text { water } \\
\text { hole }\end{array}$ & $>100$ & 7.65 & 2479 & 1.3 & 17/vii/00 \\
\hline $\mathrm{f}$ & Kueba Shingot & 5 & cavern & $>500$ & 7.14 & 7590 & 4.5 & 13/vi/01 \\
\hline $\mathrm{g}$ & Hofi Brievengat & 20 & stream & - & - & - & - & - \\
\hline $\mathrm{h}$ & Spelonk di Fuik & 5 & cavern & - & - & - & - & - \\
\hline $\mathrm{i}$ & Dam Koko & 5 & dam & - & - & - & - & - \\
\hline
\end{tabular}

* Site was almost at sea level and showed large differences in parameters over a short distance.

\& Hart (1982). This species is found from Nicaragua to Panama and throughout the Greater and Lesser Antilles, south to Trinidad (Hobbs \& Hart, 1982).

\section{Atya scabra (Leach, 1815)}

Sites. - Not collected in present survey.

Remarks. - This was one of only two species of shrimp recorded in the past, which was not collected in this study. The species is reported for Curaçao by Hobbs 
\& Hart (1982) based on two specimens collected by L. B. Holthuis at Santa Cruz in 1957. Atya scabra appears to be uncommon in Curaçao. It is a wide ranging species found from Argentina to Mexico, throughout the Caribbean and east to the west coast of Africa (Hobbs \& Hart, 1982).

\section{Micratya poeyi (Guérin-Méneville, 1855)}

Sites. - Not collected in present survey.

Remarks. - Holthuis (1977: 272) mentioned this species from Cuba, Grenada, Barbados, and Curaçao. In the collections of the RMNH two samples from Curaçao are present, both involving $1 \mathrm{spm}$. and both originating from Santa Cruz. One sample was collected by L. B. Holthuis (4 January 1957), the other by A. C. J. Burgers and I. J. Hermans on 8 May 1957. Both specimens are adult.

\section{Typhlatya monae Chace, 1954}

Sites. $-\mathrm{f}$.

Remarks. - The presence of the genus Typhlatya in cavern waters of Curaçao, Bonaire, and Aruba had been reported numerous times before (Stock, 1977a; Wagenaar-Hummelinck, 1979; Botosaneanu \& Stock, 1979, 1982; Stock, 1982) and was identified for Bonaire by Stock as Typhlatya monae, but not published (Florijn \& Visser, unpubl.). In this survey, T. monae was collected in $2 \mathrm{~m}$ of water in the cave of Shingot, Curaçao (1 spm., 13 June, 2001, RMNH D 48698, det. L. B. Holthuis). The species was also abundantly present in the brackish water cavern Spelonk di Fuik (site h) at salinities of 11 ppt, in March 1992 (Pors \& Debrot, in prep.). This distinctively small, yellowish-orange species is common in cavern waters of Bonaire, where it is most abundant below the halocline and in oxygen-depleted waters (Florijn \& Visser, unpubl). T. monae is rapidly consumed in the presence of Macrobrachium. While both species prefer fresh water, T. monae only occurs in the vicinity of the latter species in caverns with stratified waters, where it apparently can escape predation by retreating to the deeper-lying salty and oxygen-depleted waters (Florijn \& Visser, unpubl.). These records for the southern Caribbean (Curaçao and Bonaire) represent a large range extension for the species, heretofore only reported from Puerto Rico, Mona Island, the Dominican Republic, and Barbuda in the Lesser Antilles (Hobbs et al., 1977). The species is listed by the IUCN as "vulnerable", and is characterized by populations being "small or restricted" (category VU-D2) (Hilton-Taylor, 2000). 


\section{XIPHOCARIDIDAE}

Xiphocaris elongata (Guérin-Méneville, 1856)

Sites. - 2, 3, 4, 5, 10 .

Remarks. - The only prior record of this species from Curaçao is for Santa Cruz and dates from 1970 (det. L. B. Holthuis) (Kristensen, 1971, 1993). During this survey, the species was found at five sampling stations, making it the third most common species encountered. As reported by others, the species was particularly apt at evading capture by skipping across the surface of the water. The species is reported throughout the Greater and Lesser Antilles (Chace \& Hobbs, 1969).

\section{PALAEMONIDAE}

\section{Macrobrachium carcinus (Linnaeus, 1758)}

Sites. - 1, 2, 3, 4, 5, 8, 10, 14, a.

Remarks. - Previous records for Curaçao, as well as for Aruba and Bonaire, are by Chace \& Holthuis (1948; as M. jamaicense) and by Chace \& Hobbs (1969). Kristensen $(1971,1993)$ makes additional mention of this species for Santa Cruz, Curaçao. Available records for Bonaire are limited to the south-central section of the island (Punt Vierkant, Kralendijk, Lac) (Chace \& Holthuis, 1948; Florijn \& Visser, unpubl.; Kristensen, 1975). This species is the largest native freshwater shrimp of Curaçao, often reaching sizes in excess of $43 \mathrm{~mm}$ CL. It was abundantly harvested by the inhabitants of the island, principally during May 2000, from streams and behind dams on the western half of the island and represents a valuable freshwater fishery resource.

The species is widely distributed and found from Florida, throughout the Greater and Lesser Antilles, south wards to Brazil (Chace \& Hobbs, 1969). More detailed life history information on this species is provided by Lewis et al. (1966) and Choudhury (1971), while recent larval culture trials are reported by Herman et al. (1999).

\section{Macrobrachium crenulatum Holthuis, 1950}

Sites. - 1, 3, 4, 8, 14, a.

Remarks. - No prior published or unpublished records of this species for Curaçao could be found. However, $M$. crenulatum was the second most common species among the shrimps harvested by island inhabitants from streams and along dams in May 2000. Sizes were commonly in excess of $25 \mathrm{~mm}$ CL.

The species is widely distributed throughout the Greater and Lesser Antilles and has also been found from Panama to Venezuela (Chace \& Hobbs, 1969). 
Macrobrachium faustinum (De Saussure, 1857)

Sites. - 1, 4, 14 .

Remarks. - Prior records for Curaçao and Bonaire are by Rathbun (in: Boeke, 1919: 324, as M. olfersii, cf. Holthuis, 1952: 93), Chace \& Holthuis (1948), and Chace \& Hobbs (1969). Kristensen $(1971,1993)$ reports additional records for Santa Cruz, Curaçao, while Florijn \& Visser (unpubl.) provide unpublished records for many sites on Bonaire.

This species is found from the Bahamas throughout the Greater and Lesser Antilles (Chace \& Hobbs, 1969), including Venezuela (Pereira, 1991). Hunte (1980) provides information on the rearing of larvae of this species in the laboratory.

\section{Macrobrachium heterochirus (Wiegmann, 1836)}

Sites. - c.

Remarks. - The only prior mention of this species for Curaçao is by Kristensen (1971, 1993) (det. L. B. Holthuis). This species was collected at only one site during this survey (supplementary site c) and appears to be uncommon.

The species has been reported from Mexico to Brazil and throughout the Greater and Lesser Antilles (Chace \& Hobbs, 1969). Ching \& Velez (1985) provide additional information on mating, incubation, and fecundity.

\section{Macrobrachium lucifugum Holthuis, 1974}

Sites. $-\mathrm{f}$.

Remarks. - Prior records for this species for Curaçao and Bonaire are by Chace \& Holthuis (1948) (as Macrobrachium sp.) and Holthuis (1974) (as a new subspecies, M. faustinum lucifugum). Additional unpublished records are provided for Bonaire by Florijn \& Visser (unpubl.). In 1975, Chace described this as a new species, M. crybelum, while today it is known simply as M. lucifugum (cf. Hobbs, 1994). Two specimens were collected in surface waters (4.5 ppt.) from the cave of Shingot, Curaçao on 13 June 2001 (RMNH D 48699). The species is troglobitic and was not found at the 17 main epigean study sites.

It appears to be widely distributed in the West Indies and has also been reported from Cuba, the Dominican Republic, Puerto Rico, Jamaica, and Bonaire (Hobbs, 1994).

\section{DISCUSSION}

This paper presents four new and/or previously unpublished records of shrimp species for the island of Curaçao (Typhlatya monae, Xiphocaris elongata, Macrobrachium crenulatum, and $M$. heterochirus). The known freshwater shrimp fauna 
of the island now amounts to ten species. This is considerably less than on a number of other Lesser Antillean islands, such as St. Lucia and Guadeloupe (Barnish, 1984; Fièvet et al., 2001), but more than on the smaller and more arid neighbouring islands of Bonaire and Aruba. The scarcity of shrimp species in Curaçao is no doubt partly due to the general aridity of the island and the scarcity of fresh- and brackishwater habitats. Eight of the above ten species were found in the survey reported here. A record of $M$. amazonicum (Heller, 1862) erroneously ascribed to Curaçao by Bunkley-Williams \& Williams (1998) is based on specimens reported by Nierstrasz \& Brender à Brandis (1925) for Surinam (L. B. Holthuis, pers. comm.). Therefore, no records for this species exist for Curaçao.

The most common shrimps in epigean waters were $M$. carcinus, documented from eight of the 17 sites, M. crenulatum and X. elongata (respectively, at six and five of 17 sites). Epigean shrimp assemblages were clearly dominated by predatory palaemonids (Macrobrachium). The two known cavernicolous species ( $T$. monae and $M$. lucifugum) were not collected at any of the 17 main epigean collection sites but were exclusively found at the only cavern water site visited (site f). Such sites (e.g., also site h) are relatively rare on Curaçao, in contrast to Bonaire, where they are numerous (Florijn \& Visser, unpubl.).

In Curaçao, epigean freshwater shrimps are typically considered a phenomenon of the central-western sections of the island, where rainfall is somewhat higher (Meteorological Service, 1982) and nature is less disturbed. In this survey, few sites on the eastern part of the island were studied. However, earlier in the season unidentified shrimp were reported to have been abundantly harvested in a seasonal stream at Brievengat (site g). Also, Mr. G. Doran reports to have harvested large numbers of shrimp from Dam Koko (site i) in the past. Thus, while epigean freshwater shrimp indeed appear to be most common in the centralwestern sections of the island, they certainly also occur in the eastern regions.

There is a growing body of recent literature on various aspects of the ecology of West Indian freshwater shrimps (e.g., Benstead et al., 2000; Covich, 1988; Covich et al., 1996; Covich et al., 1998; Covich et al., in press; Fièvet et al., 2001; Holmquist et al., 1998; Pringle et al., 1993). Nevertheless, relatively little is known about the potential lifecycle mechanisms that would permit these species to maintain themselves on arid islands such as Curaçao.

Due to the low amount as well as the highly seasonal nature of annual rainfall in Curaçao, the freshwater epigean stream habitat, which most of the species prefer, is only available for a short period each year. During the dry season, usually lasting anywhere from 8 to 10 months annually, fresh water is extremely scarce and the question is how the shrimp fauna is able to survive that dry season. Several species are long-lived (Covich et al., in press; M. faustinum $>6$ yrs in the author's garden fish basin) and most species can tolerate a range of salinities ranging from fresh to 
brackish conditions (Ching \& Velez, 1985; Lewis et al., 1966). Therefore, possible habitats for dry season survival include (1) estuarine areas, (2) accessible pools and/or wells along the drainage areas, (3) rare feeder springs, or (4) subterranean karst waters. With respect to this latter issue, Hobbs (1994) lists four of the seven epigean species found in Curaçao as having been found in subterranean waters elsewhere, while Florijn \& Visser (unpubl.) document both of the epigean species known from Bonaire, in cavern waters on that island. Certain species appear able to survive early moults under near-seawater salinities (e.g., M. carcinus, cf. Choudhury, 1971). Therefore, some species might not even survive from year to year as adults but, circumstances permitting, (5) recruit from pelagic larvae originating from elsewhere. Any or several of these mechanisms may be used opportunistically, but which, if any, predominate for any given species requires further study.

As full larval development requires access to brackish conditions (e.g., Benstead et al., 2000), the freshwater shrimp fauna of the Caribbean is characterized by amphidromy, whereby up- or downstream migration of one or more life stages is required. High dams, which eliminate surface water flow, therefore, also eliminate the native fauna (e.g., Holmquist et al., 1998). No shrimps were found at nine of the seventeen principal sites and three of the six supplementary sites. Three of the nine principal sites that had no shrimps present were isolated by high dams, which totally cut off surface flows (sites 7, 9, 17), while four others were dam pools isolated from marine linkage due to a combination of other dams and channelization (sites 11,13,15,16). For the remaining two sites (one dam pool and one stream, respectively, sites 6 and 12), the absence of shrimps could not readily be accounted for.

Since colonization by western man, the hydrology of Curaçao has been severely altered through massive deforestation and desertification, as well as water extraction, impoundment, channelization, and contamination. The status of all freshwater shrimp species in Curaçao is precarious at best, not only because of the natural scarcity of the freshwater habitat but also because of its increasing vulnerability to anthropogenic impacts.

\section{ACKNOWLEDGMENTS}

I thank Brian Leysner, Oscar Frans, and Frank Isabella for field assistance, Klaas Dekker for the water quality measurements, and Leon Pors for drawing the map. I further thank Noris and Glen Doran for bringing me their initial specimens, which inspired this study. I am grateful to Dr. Lipke Holthuis for identifying all shrimps and for providing much additional information. Drs. Leopoldo Miranda-Castro, 
Bert Williams, Alan Covich as well as Krista Jones, Eric Newton, Tom Gilleland, and Tineke Prins are thanked for help in locating literature. This work was made possible by the Island Government of Curaçao and the Central Government of the Netherlands Antilles by means of their annual subsidy to the CARMABI Foundation.

\section{REFERENCES}

BARnish, G., 1984. The freshwater shrimps of Saint Lucia, West Indies (Decapoda, Natantia). Crustaceana, 47: 314-320.

Benstead, J. P., J. G. March \& C. M. Pringle, 2000. Estuarine larval development and upstream post-larval migration of freshwater shrimps in two rivers of Puerto Rico. Biotropica, 32: $545-548$.

Boeke, J., 1919. Rapport betreffende een voorloopig onderzoek naar de toestand van den visscherij en industrie van zeeproducten in de kolonie Curaçao, 2: 324.

Botos aneanu, L. \& J. H. Sтоск, 1979. Arubolana imula n. gen., n. sp., the first hypogean cirolanid isopod crustacean found in the Lesser Antilles. Bijdr. Dierk., Amsterdam, 49: 227233.

— — \& — - 1982. Amsterdam expeditions to the West Indian islands, Report 17. Les Cyathura stygobies (Isopoda, Anthuridae) et surtout celles des grandes et des petites Antilles. Bijdr. Dierk., Amsterdam, 52: 13-42.

Bunkley-Williams, L. \& E. H. Williams, 1998. A new freshwater shrimp host, Macrobrachium faustinum (De Saussure), and locality record, Puerto Rico, for the bopyrid isopod Probopyrus pandalicola (Packard). Caribbean Journal of Science, 34: 149-151.

Chace, F. A., 1975. Cave shrimps (Decapoda: Caridea) from the Dominican Republic. Proc. biol. Soc. Washington, 88: 29-44.

Chace, F. A. \& H. H. HobBs, 1969. The freshwater and terrestrial decapod crustaceans of the West Indies with special reference to Dominica. U.S. natn. Mus. Bull., 292: 1-258.

Chace, F. A. \& L. B. Holthuis, 1948. Land and freshwater decapod Crustacea from the Leeward Group and northern South America. Stud. Fauna Curaçao, Aruba, Bonaire \& Venezuelan Isl., 3: $21-28$.

Ching, C. A. \& M. J. Velez, 1985. Mating, incubation and embryo number in the freshwater prawn Macrobrachium heterochirus (Wiegmann, 1836) (Decapoda, Palaemonidae) under labortatory conditions. Crustaceana, 49: 42-48.

ChOudhury, P. C., 1971. Responses of larval Macrobrachium carcinus (L.) to variations in salinity and diet (Decapoda, Palaemonidae). Crustaceana, 20: 113-120.

Covich, A. P., 1988. Atyid shrimp in the headwaters of the Luquillo Mountains, Puerto Rico: filter feeding in natural and artificial streams. Verh. internat. Verein Limnol., 23: 2108-2113.

Covich, A. P., T. A. Crowl, S. L. Johnson \& M. Pyron, 1996. Distribution and abundance of tropical freshwater shrimp along a stream corridor: response to disturbance. Biotropica, 28: 484-492.

Covich, A. P., T. A. Crowl, S. L. Johnson \& F. N. Scatena, 1998. Drought effects on pool morphology and neotropical stream benthos. In: R. I. SEGARRA-GARCIA (ed.), Proceedings Tropical Hydrology and Caribbean water resources, July 12-16, 1998, San Juan, Puerto Rico: 91-96.

Covich, A. P., T. A. Crowl \& F. N. Scatena, (in press). Drought effects on freshwater shrimp in tropical headwater streams of the Luquillo Experimental Forest, Puerto Rico. Freshwat. Biol. 
Debrot, A. O. (in press). A review of the freshwater fishes of Curaçao, with comments on those of Aruba and Bonaire. Caribbean Journal of Science.

Debrot, A. O. \& R. W. M. van Soest, 2001. First records of the freshwater sponges Corvoheteromeyenia heterosclera and Spongilla alba (Porifera: Spongillidae) from Curaçao, with species descriptions and data from transplant experiments. Caribbean Journal of Science, 37: 88-94.

Fièvet, E., S. Dolédec \& P. Lim, 2001. Distribution of migratory fishes and shrimps along multivariate gradients in tropical island streams. Journ. Fish Biol., 59: 390-402.

FLORIJN, S. \& T. VIS SER, unpubl. De zoetwatergarnalenvan Bonaire: een survey en de mogelijkheden tot kweek: 1-86. (M.Sc. Thesis, University of Amsterdam, The Netherlands, 1988).

Herman, F., E. Fièvet \& P. Boucher, 1999. Potentialités et intérêts de l'élevage larvaire de la crevette d'eau douce indigène Macrobrachium carcinus (L.) (Palaemonidae) aux Antilles Françaises. Bulletin Française de la Pêche et de la Pisciculture, 352: 81-90.

Hilt ON-TAYlor, C. (ed.), 2000. 2000 IUCN red list of threatened species: 1-61. (IUCN, Gland).

Hobвs, H. H. \& C. W. HART, 1982. The shrimp genus Atya (Decapoda: Atyidae). Smithson. Contrib. Zool., 364: 1-143.

Hobвs, H. H., H. H. Hobвs, III \& M. A. Daniel, 1977. A review of the troglobitic decapod crustaceans of the Americas. Smithson. Contrib. Zool., 244: 1-183.

Новв S, H. H., III, 1994. Biogeography of subterranean decapods in North and Central America and the Caribbean region (Caridea, Astacidea, Brachyura). Hydrobiol., 287: 95-104.

Holmquist, J. G., J. M. Schmidt-Gengenbach \& B. B. Yoshiok A, 1998. High dams and marine-freshwater linkages: effects on native and introduced fauna in the Caribbean. Cons. Biol., 12: 621-630.

Holthuis, L. B., 1952. General revision of the Palaemonidae of the Americas, II. Occ. Pap. Allan Hancock Found., 12: 93.

— - 1974. Subterranean Crustacea Decapoda Macrura collected by Mr. L. Botosaneanu during the 1973 Cuban-Roumanian biospeological expedition to Cuba. Int. Journ. Speleol., 6: 231-242.

— _ 1977. On some freshwater and terrestrial Crustacea Decapoda from Cuba. In: Résultats des expéditions biospéologiques Cubano-Roumaines à Cuba: 271-275.

Hunte, W., 1980. The laboratory rearing of larvae of the shrimp Macrobrachium faustinum (Decapoda, Palaemonidae). Caribbean Journal of Science, 16: 57-60.

Kensley, B., 1981. Curassanthura halma, a new genus and species of interstitial isopod from Curaçao, West Indies (Crustacea: Isopoda: Paranthuridae). Bijdr. Dierk., Amsterdam, 51: 131134.

KRISTENSEN, I., 1971. Jaarverslag 1971. Carmabi Foundation Annual Report, Curaçao: 1-33.

— —, 1975. Jaarverslag 1975. Carmabi Foundation Annual Report, Curaçao: 1-43.

— _ 1993. Plantage Savonet: verleden en toekomst Stinapa. Carmabi Foundation, Curaçao, 35: $1-73$.

LEWIS, J. B., J. WARD \& A. MCIVER, 1966. The breeding cycle, growth, and food of the freshwater shrimp Macrobrachium carcinus (L.). Crustaceana, 10: 48-52.

Meteorological Service [of the Netherlands Antilles and Aruba], 1982. Beknopt overzicht van het klimaat van de Nederlandse Antillen. Meteorologische Dienst, Curaçao: 1-45.

Nierstrasz, H. F. \& G. A. Brender À Brandis, 1929. Bijdragen tot de kennis der fauna van Curaçao. Resultaten eener reis van C. J. van der Horst in 1920. Epicaridea. Bijdr. Dierk., Amsterdam, 24: 1-8.

Pereira, G. A., 1991. Freshwater shrimps from Venezuela II: new records in the families Atyidae and Palaemonidae (Crustacea, Decapoda, Caridea). Acta Biologica Venezuelica, 13: 75-88.

Pringle, C. M., G. A. Blake, A. P. Covich, K. M. Buzby \& A. Finley, 1993. Effects of omnivorous shrimp in a montane tropical stream: sediment removal, disturbance of sessile invertebrates and enhancement of understory algal biomass. Oecologia, 93: 1-11. 
Sтоск, J. H., 1976a. A new genus and two new species of the crustacean order Thermosbaenacea from the West Indies. Bijdr. Dierk., Amsterdam, 46: 47-70.

_ - 1976b. A new member of the crustacean suborder Ingolfiellidae from Bonaire, with a review of the entire suborder. Stud. Fauna Curaçao Caribbean Isl., 50: 56-76.

— _ 1977a. Microparasellidae (Isopoda, Asellota) from Bonaire, with notes on the origin of the family. Stud. Fauna Curaçao Caribbean Isl., 51: 69-91.

— - 1977b. The taxonomy and zoogeography of the hadziid Amphipoda, with emphasis on the West Indian taxa. Stud. Fauna Curaçao Caribbean Isl., 55: 1-130.

- $-1977 \mathrm{c}$. The zoogeography of the crustacean suborder Ingolfiellidea, with descriptions of new West Indian taxa. Stud. Fauna Curaçao Caribbean Isl., 55: 131-146.

— - 1979. Amsterdam expeditions to the West Indian Islands, Report 2. New data on taxonomy and zoogeography of ingolfiellid Crustacea. Bijdr. Dierk., Amsterdam, 49: 81-97.

— - 1980. Amsterdam expeditions to the West Indian Islands, Report 8. A new cave amphipod (Crustacea) from Curaçao: Psammogammarus caesicolus n. sp. Bijdr. Dierk., Amsterdam, 50: 375-386.

— - 1982. Amsterdam expeditions to the West Indian Islands, Report 18. Stygobiont Crustacea Malacostraca from geologically older and younger Antillean islands: a biogeographic analysis. Bijdr. Dierk., Amsterdam, 52: 191-199.

Stork, H. A., 1940. A new fresh-water isopod from Curaçao. Stud. Fauna Curaçao, Aruba, Bonaire \& Venezuelan Isl., 2: 147-150.

WÄGELE, J. W., 1982. Amsterdam expeditions to the West Indian Islands, Report 10. The hypogean Paranthuridae Cruregens Chilton and Curassanthura Kensley (Crustacea, Isopoda), with remarks on their morphology and adaptations. Bijdr. Dierk., Amsterdam, 52: 49-59.

WagenaAR-Hummelinck, P., 1979. Caves of the Netherlands Antilles: 1-176. (Found. Sci. Res. Surinam \& Netherlands Antilles, Utrecht). 